\title{
Development and Validation of Postoperative Venous Thromboembolism risk prediction model
}

Sang H. Woo ${ }^{1}$, Ruben Rhoades ${ }^{2}$, Lily Ackermann ${ }^{1}$, Scott W. Cowan ${ }^{3}$, Jillian Zavodnick ${ }^{1}$, Gregary D. Marhefka ${ }^{4}$,

1 Department of Medicine- Division of Hospital Medicine, Thomas Jefferson University, Philadelphia, PA 19107

${ }^{2}$ Department of Medicine- Division of Hematology, Thomas Jefferson University, Philadelphia, PA 19107

${ }^{3}$ Department of Surgery, Thomas Jefferson University, Philadelphia, PA 19107

${ }^{4}$ Department of Medicine- Division of Cardiology, Thomas Jefferson University, Philadelphia, PA 19107

Running title: preoperative VTE risk assessment

Keywords: VTE, Deep Vein Thrombosis, Pulmonary Embolism, risk, model, machine learning

Correspondence: Sang Hoon Woo, M.D.

Division of Hospital Medicine, Department of Medicine, Thomas Jefferson University Suite 701, 833 Chestnut St., Philadelphia, PA 19107

email: sang.woo@jefferson.edu

The authors have no conflicts of interest to disclose related to this manuscript.

No funding was obtained for this manuscript.

The content of this manuscript was not presented at any prior conferences 
medRxiv preprint doi: https://doi.org/10.1101/2020.06.21.20136432; this version posted June 23, 2020. The copyright holder for this preprint (which was not certified by peer review) is the author/funder, who has granted medRxiv a license to display the preprint in perpetuity.

All rights reserved. No reuse allowed without permission.

\begin{abstract}
:
Background: VTE is a serious postoperative complication after surgery with resultant higher morbidity and mortality. Despite years of experience with current risk models, rates continue to be high and more information is needed on individual patient risk in the prophylaxis era.
\end{abstract}

Research Questions: Can we assess the individualized risk of postoperative venous thromboembolism (VTE) for broad categories of surgery?

Methods: This study was performed using data from the American College of Surgeons National Surgical Quality Improvement Program (ACS-NSQIP) Database. Patient data $(n=2,875,190)$ from 2015-2017 were used for study analysis. Eight predictors were selected for the model: age, preoperative platelet count $\geq 450\left(\times 10^{9} / \mathrm{L}\right)$, disseminated cancer, corticosteroid use, serum albumin $\leq 2.5 \mathrm{~g} / \mathrm{dL}$, preoperative sepsis, hospital length of stay and surgery type. The second model included 7 predictors without hospital length of stay. A predictive model was trained using ACS-NSQIP data from 2015-2016 ( $\mathrm{n}=1,859,227)$ and tested using data from 2017 $(n=1,015,963)$. Primary outcomes are postoperative 30-day VTE, including deep vein thrombosis (DVT) and/or pulmonary embolism (PE).

Results: VTE occurred in 23,249 patients $(0.81 \%)$ and $49.9 \%$ of VTE occurred after discharge from index hospitalization. The risk prediction model had high AUC (area under the receiver operating characteristic curve) for postoperative VTE of 0.78 (training cohort) and 0.78 (test cohort).

Interpretation: This clinical prediction model is a validated, practical and easy-to-use tool to identify surgical patients at the highest risk of postoperative VTE and provide an individualized 2 
medRxiv preprint doi: https://doi.org/10.1101/2020.06.21.20136432; this version posted June 23, 2020. The copyright holder for this preprint (which was not certified by peer review) is the author/funder, who has granted medRxiv a license to display the preprint in perpetuity.

All rights reserved. No reuse allowed without permission.

assessment of risk based on clinical factors and type of surgery. This prediction model may be used as a tool to assess individualized risk of postoperative VTE and promote broader discussion and awareness of the VTE risk during the perioperative period.

\section{INTRODUCTION:}

Large numbers of surgical and medical patients are at risk of venous thromboembolism. ${ }^{1,2}$ Postoperative deep venous thrombosis (DVT) and pulmonary embolism (PE) are major surgical complications with high mortality and morbidity. ${ }^{3-5}$ To reduce the risk of these complications, the American College of Chest Physicians (ACCP) published guidelines recommending the use of pharmacologic and/or mechanical prophylaxis according to risk scores. ${ }^{6}$ Despite the use of various thromboprophylaxis methods, the incidence of postoperative venous thromboembolism remains high. ${ }^{7}$ Accurate assessment of a patient's VTE risk helps to foster awareness and discussion with the patient and the surgeon during the perioperative period while increasing compliance with evolving prophylaxis guidelines.

Various qualitative and quantitative risk assessment models have been developed and are in use. 8-11 However, currently available venous thromboembolism risk assessment models have limitations. The modified Caprini Risk Assessment model and the Rogers score have been frequently used, ${ }^{8}$ but these models were developed from a limited number of surgical procedures and before current pharmacologic prophylaxis methods, such as low molecular weight heparin (LMWH) and direct oral anticoagulants (DOACs), were widely utilized. Thus, a need exists for a 
medRxiv preprint doi: https://doi.org/10.1101/2020.06.21.20136432; this version posted June 23, 2020. The copyright holder for this preprint (which was not certified by peer review) is the author/funder, who has granted medRxiv a license to display the preprint in perpetuity.

All rights reserved. No reuse allowed without permission.

risk assessment model developed from a contemporary patient population, that is applicable to -and validated in -- broader types of surgery.

Pharmacologic methods for postoperative VTE prophylaxis are highly variable, including aspirin, unfractionated heparin, LMWH, or DOACs. Current guidelines allow the use of different anticoagulation approaches but provide limited guidance for which patients warrant which pharmacologic method. More targeted, individualized preventive measures for patients at particularly high risk may help further lower rates of VTE by guiding clinicians toward more

aggressive prophylaxis. ${ }^{12} 6$ In order to accurately assess an individual's risk, development of a quantitative risk assessment of VTE is necessary that can be applied to broad types of surgery, which may necessitate different types of DVT prophylaxis.

This analysis was performed using the American College of Surgeons National Surgical Quality Improvement Program (ACS-NSQIP) database.

METHODS:

\section{Study design, population}

The ACS-NSQIP database is a prospective database of patients undergoing surgery at more than 500 US and international, academic and community hospitals. Data including preoperative demographics, risk factors, and 30-day postoperative outcomes are obtained by trained surgical clinical reviewers at each participating hospital for submission to the database. To develop this model, we analyzed 2,875,190 patients in the ACS-NSQIP database from 2015 to 2017. 
Risk factors included in our analysis were age, sex, smoking, history of congestive heart failure, history of chronic obstructive pulmonary disease, diabetes, preoperative sepsis, use of antihypertensive medications, chronic corticosteroid use, disseminated cancer, dialysis, preoperative renal failure, admission origin, body mass index, admission type (inpatient, outpatient status), American Society of Anesthesiologists' (ASA) class, preoperative functional status, and the type of surgery. Preoperative laboratory tests in the analysis include serum sodium, creatinine, white blood cell count, hematocrit, and platelet count.

\section{Outcome}

Occurrence of VTE, including DVT and/or PE, within 30 days of surgery was the primary outcome.

\section{Data Analysis}

The predictive model was trained using data from years 2015 and $2106(\mathrm{~N}=1,859,227)$ and validated using data from $2017(\mathrm{~N}=1,015,963)$. Clinical predictors to be included in the predictive model were selected using backwards elimination, clinical relevance and related literature. Predictors considered for the model were selected without knowing the outcome based on the literature. Multivariate logistic regression analysis was performed to obtain covariate coefficient, standard error, and adjusted odd's ratio. Missing lab values (hematocrit, platelet, albumin, white blood cell count) were recorded as a separate category. Patient 
medRxiv preprint doi: https://doi.org/10.1101/2020.06.21.20136432; this version posted June 23, 2020. The copyright holder for this preprint (which was not certified by peer review) is the author/funder, who has granted medRxiv a license to display the preprint in perpetuity.

All rights reserved. No reuse allowed without permission.

demographic factors were compared using Chi-squared tests for categorical variables and Wilcoxon for continuous variables.

AUC(Area Under the Curve) was used to evaluate the model performance. We used GridSearchCV package with 5 fold cross validation to determine the best model parameters. Statistical analysis was done using Python (version 3.6.6), Statsmodels (version 0.9.0), and r programming (RStudio version 1.1.463). Scikit-learn package was used for machine learning modeling and web application. The Thomas Jefferson University Institutional Review Board approved this study and granted a waiver of informed consent from study participants.

\section{Results}

\section{Patient population}

Table 1 shows demographic characteristics of study participant cohorts. VTE occurrence rate was $0.82 \%(n=15,159)$ in 2015 to 2016 . Patients who developed VTE were older (63.4 vs 56.5 years, $\mathrm{p}<0.001)$. Patients with postoperative VTE had higher prevalence of disseminated cancer (8.75\% vs $2.22 \%, \mathrm{p}<0.001)$, insulin dependent diabetes $(7.64 \%$ vs $5.78 \%, \mathrm{p}<0.001)$, dialysis $(2.03 \%$ v $1.31 \%, \mathrm{p}<0.001)$, and COPD $(7.96 \%$ vs $4.45 \%, \mathrm{p}<0.001)$. Figure 1 shows 30-day mortality and readmission rates associated with the occurrences of VTE. Patient who developed VTE had higher rates of death (5.9\% vs $0.9 \%)$, and 30 day readmission rates $(37.5 \%$ vs $5.0 \%)$

\section{Age, Platelet Count, Serum Albumin and Incidence of VTE}


medRxiv preprint doi: https://doi.org/10.1101/2020.06.21.20136432; this version posted June 23, 2020. The copyright holder for this preprint (which was not certified by peer review) is the author/funder, who has granted medRxiv a license to display the preprint in perpetuity.

All rights reserved. No reuse allowed without permission.

Figure 2 illustrates the unadjusted rates of postoperative VTE according to age, platelet count, and serum albumin level from years 2015 to 2017. Both thrombocytopenia and thrombocytosis were associated with increased unadjusted postoperative VTE rate. Patients with thrombocytosis with platelets of $\geq 450\left(\times 10^{9} / \mathrm{L}\right)$ had a VTE rate of $2.2 \%$ compared with $0.9 \%$ for patients with platelets of $<450\left(\times 10^{9} / \mathrm{L}\right)$. Older age was associated with higher incidence of VTE. Patients age $71-80$ years had a VTE rate of $1.2 \%$, compared with $0.71 \%$ for age $46-60$ years.

A low serum albumin level was associated with a higher incidence of VTE. Those with a serum albumin $\leq 2.5 \mathrm{~g} / \mathrm{dL}$ had a VTE incidence of $3.71 \%$, compared with $1.0 \%$ for those with albumin $>2.5 \mathrm{~g} / \mathrm{dL}$.

\section{Surgery type and VTE}

30-day postoperative VTE rates vary significantly among different types of surgery. Figure 3 shows VTE rates according to type of surgery from 2015 to 2016 cohorts. Compared with rates of $<2 \%$ for other surgery types, surgeries involving the liver, pancreas, or spleen $(3.08 \%)$, brain (2.84\%), and vascular-aorta $(2.36 \%)$ were associated with higher VTE rates. Among orthopedic surgeries, lower extremity and pelvic surgeries were associated with higher VTE rates compared to upper extremity or shoulder surgery $(1.10 \%$ vs $0.33 \%)$.

$49.91 \%$ of DVT and $49.93 \%$ of PE complications occurred after discharge from index hospitalization. eFigure $\mathbf{V}$ in the Supplement shows the average day from operation until DVT complication according to surgery type. 


\section{Prediction and validation of the predictive model}

Table 2 shows eight predictors selected for the VTE risk assessment model. Age, disseminated cancer, hypoalbuminemia (albumin $\leq 2.5 \mathrm{~g} / \mathrm{dL}$ ), corticosteroid use and hospital length of stay had significant association with 30-day postoperative DVT occurrence. Patients with low serum albumin (albumin $\leq 2.5 \mathrm{~g} / \mathrm{dL})$ had a high adjusted odds ratio (OR=1.17, $\mathrm{P}<0.001)$. Thrombocytosis (platelet $\geq 450 \times 10^{9} / \mathrm{L}$ ) also had a high adjusted odds ratio $(\mathrm{OR}=1.38, \mathrm{P}<0.001)$.

As shown in eFigure II in the Supplement, the model has excellent calibration. The VTE prediction model has excellent model performance (training cohort $\mathrm{AUC}=0.78$, validation cohort AUC=0.78). Brier score was 0.008. 5-fold cross validation method for the training cohort showed mean AUC of 0.79 .

\section{Prediction model of 30-day postoperative VTE without hospital length of stay}

The prediction model for postoperative VTE using the seven predictors (excluding hospital length of stay) showed high predictive power (training cohort $\mathrm{AUC}=0.74$, validation cohort $\mathrm{AUC}=0.75)$. Brier score was 0.008. Predictors of this model are available in eTable I of the Supplement. The calibration plot is shown in eFigure III of the Supplement. 
medRxiv preprint doi: https://doi.org/10.1101/2020.06.21.20136432; this version posted June 23, 2020. The copyright holder for this preprint (which was not certified by peer review) is the author/funder, who has granted medRxiv a license to display the preprint in perpetuity.

All rights reserved. No reuse allowed without permission.

\section{Application of the Risk Model}

Below are example use cases for the VTE risk calculator. A VTE probability (\%) can be calculated using the intercept and coefficient from multivariate logistic regression model. A web-based risk model is available for use at the bedside (http://vterisk.herokuapp.com).

1. 67 year old male, with a history of disseminated cancer, on outpatient corticosteroid treatment, no preoperative sepsis, serum albumin $2.0 \mathrm{~g} / \mathrm{dL}$, platelet count $110 \times 10^{9} / \mathrm{L}$, spine surgery: 30 -day postoperative VTE risk $=6.47 \%$ (eFigure IV in the Supplement)

2. 60 year old female, no history of cancer, history of rheumatoid arthritis on corticosteroid treatment, no preoperative sepsis, serum albumin $3.5 \mathrm{~g} / \mathrm{dL}$, platelet count $130 \times 10^{9} / \mathrm{L}$, hip replacement surgery, expected hospital length of stay 4 days: VTE risk $=1.35 \%$, expected hospital length of stay 8 days: VTE risk $=1.81 \%$

\section{Discussion}

Our study developed a predictive model of 30-day postoperative VTE, using a very large dataset of patients undergoing diverse types of surgery. Using eight easily available clinical and laboratory factors, this model displayed excellent predictive performance.

How could this model be used to decrease the rate of postoperative VTE? Accurate assessment of the highest risk patients and measures such as extended prophylaxis may have a significant impact on post-surgical outcomes and mortality. Despite varying VTE risk within surgery type, patient factors portend very different risks even within the same type of surgery. For example, patients with lower extremity orthopedic surgery had a wide distribution of VTE risk, from 
medRxiv preprint doi: https://doi.org/10.1101/2020.06.21.20136432; this version posted June 23, 2020. The copyright holder for this preprint (which was not certified by peer review) is the author/funder, who has granted medRxiv a license to display the preprint in perpetuity.

All rights reserved. No reuse allowed without permission.

nearly $0 \%$ to over $8 \%$, so VTE preventive measures may need to be further individualized. In patients with high VTE risk, extended use of pharmacologic therapy after discharge may decrease VTE occurrence. ACCP (American College of Chest Physicians) 2012 guidelines suggested extending thromboprophylaxis for up to 35 days for major orthopedic surgery (Grade 2B). ${ }^{13}$ ACCP 2012 guidelines also recommended pharmacologic prophylaxis for 4 weeks with LMWH for patients at high risk for VTE undergoing abdominal or pelvic surgery for cancer who are not otherwise at high risk for major bleeding (Grade 1B) ${ }^{6,13}$ Our study showed that $49.9 \%$ of VTE complications occurred after discharge from initial hospitalization, consistent with other studies. ${ }^{14,15}$ Extended thromboprophylaxis could be more broadly applied with a better determination of an individual's risk, which our model provides. A prospective, observational study in 2373 patients undergoing cancer surgery demonstrated that VTE was the most common cause of mortality, responsible for $46.3 \%$ of postoperative deaths. ${ }^{16}$

Our study found that certain non-orthopedic surgeries, such as intestinal, vascular, and liver surgery, were associated with higher rates of DVT than orthopedic surgery. Abdominal procedures may overlap with oncologic surgery, a group of patients among which the incidence of VTE is high, with one study detecting occult postoperative DVT by surveillance duplex in $9.8 \%$ of patients despite the use of perioperative thromboprophylaxis. ${ }^{17}$ For vascular surgery patients, who have a high incidence of postoperative VTE, the use of both mechanical and pharmacologic prophylaxis in the preoperative period led to a $75 \%$ reduction in postoperative VTE in one single center study. ${ }^{18}$ Further study is necessary to investigate whether initiation of intensive preoperative prophylaxis, and extended post-operative pharmacologic therapy would be beneficial following these highest risk procedures. 
medRxiv preprint doi: https://doi.org/10.1101/2020.06.21.20136432; this version posted June 23, 2020. The copyright holder for this preprint (which was not certified by peer review) is the author/funder, who has granted medRxiv a license to display the preprint in perpetuity.

All rights reserved. No reuse allowed without permission.

As demonstrated in the case examples, VTE risk is not fixed, but changes according to factors such as hospital length of stay. The Caprini score incorporates a large number of variables, but does not include hospital length of stay. If a patient stays in the hospital longer than expected length of stay, risk of VTE may increase, so reconsideration of VTE risk and modification of preventive measures may be necessary.

Low serum albumin was shown to be associated with an increased risk of VTE in large cohort studies and likely reflects a hyperinflammatory and/or hypercoagulable state. 19-21 Hypoalbuminemia was a risk factor for VTE after colorectal surgery. ${ }^{22,23}$ The risk of VTE was increased among systemic glucocorticoid users, consistent with other studies. ${ }^{24,25}$ As a possible explanation, one study demonstrated that glucocorticoids may increase the activity of prothrombotic factors. ${ }^{26}$

Our study has certain strengths. First, the model was trained and validated on over 2.8 million patients across varied types of surgery, so this model is applicable to broad types of surgery compared with the modified Caprini Risk Assessment Model, which was validated in a limited number of surgery types and a significantly smaller patient population. Second, this model is derived from more recent data (2015 to 2017), when pharmacologic and mechanical thromboprophylaxis were commonly used, unlike the modified Caprini Risk Assessment Model, which was developed originally in 1991 and included only $37.2 \%$ receiving VTE prophylaxis. ${ }^{8}$ The use of VTE prophylaxis in surgical patients has increased significantly over the past two decades. ${ }^{27}$ Third, the VTE model performance was superior or equal to other models such as Rogers (AUC 0.76), IMPROVE (AUC 0.65), and Premier (AUC 0.75) . ${ }^{2828-309}$ 
medRxiv preprint doi: https://doi.org/10.1101/2020.06.21.20136432; this version posted June 23, 2020. The copyright holder for this preprint (which was not certified by peer review) is the author/funder, who has granted medRxiv a license to display the preprint in perpetuity.

All rights reserved. No reuse allowed without permission.

The current study does have limitations. First, a history of DVTs was not included in the model as these data were not available in the ACS-NSQIP database. Second, we do not know which participants in the cohort were treated with pharmacologic preventive therapy in the perioperative period. Also, the NSQIP database does not include information on postdischarge medications, such as prolonged postdischarge VTE prophylaxis

In conclusion, this VTE risk assessment model for postoperative patients was developed and validated with a very large number of patients across a wide variety of procedures. This easy-touse model utilizes a limited number of readily available variables and can help clinicians accurately and easily identify patients at the highest risk of VTE events, promote broader discussion and awareness between the patient and the surgeon during the perioperative period, and improve surgical morbidity and mortality.

\section{$\underline{\text { Acknowledgments }}$}

Dr. Woo had full access to all the data in the study and takes responsibility for the integrity of the data and the accuracy of the data analysis.

The American College of Surgeons National Surgical Quality Improvement Program and the hospitals participating in the ACS NSQIP are the source of the data used herein; they have not verified and are not responsible for the statistical validity of the data analysis or the conclusions derived by the authors. 
Funding/Support: no funding

Disclosures:

None

\section{FIGURES AND TABLES LEGENDS}

Figure 1. 30-day postoperative mortality and readmission rates with venous thromboembolism

Figure 2. Age, Platelet count, Serum Albumin Length of Stay and unadjusted VTE rates. Patients from 2015 to 2017

Figure 3. VTE rates (\%) according to type of surgery (patients from 2015-16)

Table 1. Characteristics of the patients (patients from 2015 to 2016)

Table 2. Adjusted odds ratio (OR) of VTE predictors

[Supplement]

eFigure I. Study participant flow chart

eFigure II. Calibration plot for 30-day postoperative VTE (Model with hospital length of stay) Observed vs expected VTE risk

eFigure III. Calibration plot for 30-day postoperative VTE (Model without length of stay). Observed vs expected VTE risk

eFigure IV. Mobile web-application of VTE prediction model

eFigure V. Average day from operation until DVT complication according to surgery type

eTable I. Predictors of VTE predictors (without length of stay) 
Bibliography

1. Anderson FA, Zayaruzny M, Heit JA, Fidan D, Cohen AT. Estimated annual numbers of US acutecare hospital patients at risk for venous thromboembolism. Am J Hematol. 2007;82(9):777-782. doi:10.1002/ajh.20983

2. White RH, Zhou H, Romano PS. Incidence of symptomatic venous thromboembolism after different elective or urgent surgical procedures. Thromb Haemost. 2003;90(3):446-455. doi:10.1160/TH03-03-0152

3. Lindblad B, Eriksson A, Bergqvist D. Autopsy-verified pulmonary embolism in a surgical department: analysis of the period from 1951 to 1988. Br J Surg. 1991;78(7):849-852.

4. Rasmussen MS, Wille-Jørgensen P, Jorgensen LN. Postoperative fatal pulmonary embolism in a general surgical department. Am J Surg. 1995;169(2):214-216. doi:10.1016/S0002-9610(99)801391

5. Bergqvist D, Lindblad B. A 30-year survey of pulmonary embolism verified at autopsy: an analysis of 1274 surgical patients. Br J Surg. 1985;72(2):105-108. doi:10.1002/bjs.1800720211

6. Gould MK, Garcia DA, Wren SM, et al. Prevention of VTE in nonorthopedic surgical patients: Antithrombotic Therapy and Prevention of Thrombosis, 9th ed: American College of Chest Physicians Evidence-Based Clinical Practice Guidelines. Chest. 2012;141(2 Suppl):e227S-77S. doi:10.1378/chest.11-2297

7. Schiff RL, Kahn SR, Shrier I, et al. Identifying orthopedic patients at high risk for venous thromboembolism despite thromboprophylaxis. Chest. 2005;128(5):3364-3371. doi:10.1378/chest.128.5.3364

8. Caprini JA, Arcelus JI, Hasty JH, Tamhane AC, Fabrega F. Clinical assessment of venous thromboembolic risk in surgical patients. Semin Thromb Hemost. 1991;17 Suppl 3:304-312.

9. Kucher N, Koo S, Quiroz R, et al. Electronic alerts to prevent venous thromboembolism among hospitalized patients. N Engl J Med. 2005;352(10):969-977. doi:10.1056/NEJMoa041533

10. Geerts WH, Bergqvist D, Pineo GF, et al. Prevention of venous thromboembolism: American College of Chest Physicians Evidence-Based Clinical Practice Guidelines (8th Edition). Chest. 2008;133(6 Suppl):381S-453S. doi:10.1378/chest.08-0656 
medRxiv preprint doi: https://doi.org/10.1101/2020.06.21.20136432; this version posted June 23, 2020. The copyright holder for this preprint (which was not certified by peer review) is the author/funder, who has granted medRxiv a license to display the preprint in perpetuity.

All rights reserved. No reuse allowed without permission.

11. Chopard P, Spirk D, Bounameaux H. Identifying acutely ill medical patients requiring thromboprophylaxis. J Thromb Haemost. 2006;4(4):915-916. doi:10.1111/j.1538-

7836.2006.01818.x

12. Cassidy MR, Rosenkranz P, McAneny D. Reducing postoperative venous thromboembolism complications with a standardized risk-stratified prophylaxis protocol and mobilization program. $J$ Am Coll Surg. 2014;218(6):1095-1104. doi:10.1016/j.jamcollsurg.2013.12.061

13. Falck-Ytter Y, Francis CW, Johanson NA, et al. Prevention of VTE in orthopedic surgery patients: Antithrombotic Therapy and Prevention of Thrombosis, 9th ed: American College of Chest Physicians Evidence-Based Clinical Practice Guidelines. Chest. 2012;141(2 Suppl):e278S-325S. doi:10.1378/chest.11-2404

14. Salous AK, Reyad A, Sweeney K, Mavanur A. A significant proportion of venous thromboembolism events in general surgical patients occurs after discharge: analysis of the ACSNSQIP Essentials database. Perioper Med (Lond). 2019;8:18. doi:10.1186/s13741-019-0131-1

15. Bouras G, Burns EM, Howell A-M, Bottle A, Athanasiou T, Darzi A. Risk of Post-Discharge Venous Thromboembolism and Associated Mortality in General Surgery: A Population-Based Cohort Study Using Linked Hospital and Primary Care Data in England. PLoS ONE. 2015;10(12):e0145759. doi:10.1371/journal.pone.0145759

16. Agnelli G, Bolis G, Capussotti L, et al. A clinical outcome-based prospective study on venous thromboembolism after cancer surgery: the @ RISTOS project. Ann Surg. 2006;243(1):89-95. doi:10.1097/01.sla.0000193959.44677.48

17. Sinnamon AJ, Tong JKC, Bailey EA, et al. Prospective implementation of a standardized screening protocol for deep venous thrombosis in abdominal surgical oncology patients. J Surg Oncol. 2018;118(3):568-573. doi:10.1002/jso.25151

18. Durinka JB, Hecht TE, Layne AJ, et al. Aggressive venous thromboembolism prophylaxis reduces VTE events in vascular surgery patients. Vascular. 2016;24(3):233-240. doi:10.1177/1708538115594094

19. Folsom AR, Lutsey PL, Heckbert SR, Cushman M. Serum albumin and risk of venous thromboembolism. Thromb Haemost. 2010;104(1):100-104. doi:10.1160/TH09-12-0856

20. Northup PG, McMahon MM, Ruhl AP, et al. Coagulopathy does not fully protect hospitalized cirrhosis patients from peripheral venous thromboembolism. Am J Gastroenterol. 2006;101(7):1524-1528; quiz 1680. doi:10.1111/j.1572-0241.2006.00588.x

21. Gyamlani G, Molnar MZ, Lu JL, Sumida K, Kalantar-Zadeh K, Kovesdy CP. Association of serum albumin level and venous thromboembolic events in a large cohort of patients with nephrotic syndrome. Nephrol Dial Transplant. 2017;32(1):157-164. doi:10.1093/ndt/gfw227

22. Shapiro R, Vogel JD, Kiran RP. Risk of postoperative venous thromboembolism after laparoscopic and open colorectal surgery: an additional benefit of the minimally invasive approach? Dis Colon Rectum. 2011;54(12):1496-1502. doi:10.1097/DCR.0b013e31823302a1

23. Moghadamyeghaneh Z, Hanna MH, Carmichael JC, Nguyen NT, Stamos MJ. A nationwide analysis of postoperative deep vein thrombosis and pulmonary embolism in colon and rectal 
medRxiv preprint doi: https://doi.org/10.1101/2020.06.21.20136432; this version posted June 23, 2020. The copyright holder for this preprint (which was not certified by peer review) is the author/funder, who has granted medRxiv a license to display the preprint in perpetuity.

All rights reserved. No reuse allowed without permission.

surgery. J Gastrointest Surg. 2014;18(12):2169-2177. doi:10.1007/s11605-014-2647-5

24. Johannesdottir SA, Horváth-Puhó E, Dekkers OM, et al. Use of glucocorticoids and risk of venous thromboembolism: a nationwide population-based case-control study. JAMA Intern Med. 2013;173(9):743-752. doi:10.1001/jamainternmed.2013.122

25. Lieber BA, Han J, Appelboom G, et al. Association of Steroid Use with Deep Venous Thrombosis and Pulmonary Embolism in Neurosurgical Patients: A National Database Analysis. World Neurosurg. 2016;89:126-132. doi:10.1016/j.wneu.2016.01.033

26. Brotman DJ, Girod JP, Posch A, et al. Effects of short-term glucocorticoids on hemostatic factors in healthy volunteers. Thromb Res. 2006;118(2):247-252. doi:10.1016/j.thromres.2005.06.006

27. Colorectal Writing Group for Surgical Care and Outcomes Assessment Program-Comparative Effectiveness Research Translation Network (SCOAP-CERTAIN) Collaborative, Nelson DW, Simianu VV, et al. Thromboembolic complications and prophylaxis patterns in colorectal surgery. JAMA Surg. 2015;150(8):712-720. doi:10.1001/jamasurg.2015.1057

28. Rogers SO, Kilaru RK, Hosokawa P, Henderson WG, Zinner MJ, Khuri SF. Multivariable predictors of postoperative venous thromboembolic events after general and vascular surgery: results from the patient safety in surgery study. J Am Coll Surg. 2007;204(6):1211-1221. doi:10.1016/j.jamcollsurg.2007.02.072

29. Rothberg MB, Lindenauer PK, Lahti M, Pekow PS, Selker HP. Risk factor model to predict venous thromboembolism in hospitalized medical patients. J Hosp Med. 2011;6(4):202-209. doi: $10.1002 / \mathrm{jhm} .888$

30. Agency for Healthcare Research \& Quality. Efforts To Improve Patient Safety Result in 1.3 Million Fewer Patient Harms. https://www.ahrq.gov/professionals/quality-patientsafety/pfp/interimhacrate2013.html. Published 2014. Accessed February 4, 2018. 
Table 1. Characteristics of the patients (patients from 2015 to 2016)

\begin{tabular}{|c|c|c|c|}
\hline & $\begin{array}{c}\text { No VTE } \\
(\mathrm{n}=1,844,068)\end{array}$ & $\begin{array}{c}\text { VTE } \\
(n=15,159)\end{array}$ & P-value \\
\hline Age $($ Mean \pm SD) & $56.5 \pm 16.8$ & $63.4 \pm 14.9$ & $*$ \\
\hline Sex (Male) & 43.33 & 48.33 & * \\
\hline Insulin Dependent Diabetes (\%) & 5.78 & 7.64 & $*$ \\
\hline Disseminated cancer(\%) & 2.22 & 8.75 & * \\
\hline $\begin{array}{c}\text { Hypertension medication } \\
\text { use }(\%)\end{array}$ & 44.80 & 55.68 & $*$ \\
\hline $\operatorname{Ascites}(\%)$ & 0.31 & 1.55 & $*$ \\
\hline Weight loss(\%) & 1.18 & 4.18 & $*$ \\
\hline Emergency $(\%)$ & 8.87 & 16.68 & $*$ \\
\hline $\operatorname{COPD}(\%)$ & 4.45 & 7.96 & * \\
\hline Congestive Heart Failure (\%) & 0.88 & 2.03 & $*$ \\
\hline Smoking $(\%)$ & 17.79 & 16.43 & $*$ \\
\hline Renal Failure(\%) & 0.35 & 1.11 & $*$ \\
\hline Dialysis(\%) & 1.31 & 2.03 & $*$ \\
\hline Corticosteroid use(\%) & 3.57 & 8.01 & $*$ \\
\hline Bleeding disorder $(\%)$ & 4.07 & 8.31 & $*$ \\
\hline White Blood Cell Count $\left(\times 10^{9} / \mathrm{L}\right)$ & 8.17 & 9.05 & $*$ \\
\hline
\end{tabular}


medRxiv preprint doi: https://doi.org/10.1101/2020.06.21.20136432; this version posted June 23, 2020. The copyright holder for this preprint (which was not certified by peer review) is the author/funder, who has granted medRxiv a license to display the preprint in perpetuity.

\begin{tabular}{|c|c|c|c|}
\hline Hematocrit $(\%)$ & 39.7 & 37.9 & $*$ \\
\hline Platelet $\left(\mathrm{x} 10^{9} / \mathrm{L}\right)$ & 249.19 & 255.67 & 0.51 \\
\hline Serum Albumin $(\mathrm{g} / \mathrm{dL})$ & 3.91 & 3.53 & $*$ \\
\hline Serum Sodium $(\mathrm{mEq} / \mathrm{L})$ & 139.06 & 138.74 & $*$ \\
\hline Serum Creatinine $(\mathrm{mg} / \mathrm{dL})$ & 1.01 & 1.07 & $*$ \\
\hline
\end{tabular}

$* \mathrm{p}<0.001$

Table 2. Adjusted odds ratio (OR) of VTE predictors

\begin{tabular}{|c|c|c|c|c|}
\hline & Adjusted odds ratio & coefficient & SE & P-Value \\
\hline Intercept & & -6.954 & 0.146 & $<0.001$ \\
\hline Age & $1.02(1.01-1.02)$ & 0.015 & 0.001 & $<0.001$ \\
\hline Steroid use & $1.44(1.35-1.53)$ & 0.364 & 0.032 & $<0.001$ \\
\hline Disseminated cancer & $1.93(1.81-2.05)$ & 0.655 & 0.031 & $<0.001$ \\
\hline Albumin $\leq 2.5$ g/dL & $1.17(1.09-1.25)$ & 0.154 & 0.035 & $<0.001$ \\
\hline Sepsis (reference =none) & $1.57(1.46-1.68)$ & 0.449 & 0.036 & $<0.001$ \\
\hline SIRS & $1.65(1.53-1.78)$ & 0.499 & 0.038 & $<0.001$ \\
\hline Sepsis & $2(1.79-2.24)$ & 0.694 & 0.058 & $<0.001$ \\
\hline
\end{tabular}




\begin{tabular}{|c|c|c|c|c|}
\hline $\begin{array}{l}\text { Platelet }\left(\times 10^{9} / \mathrm{L}\right) \\
\text { (reference }=0-449)\end{array}$ & & & & \\
\hline$\geq 450$ & $1.38(1.27-1.5)$ & 0.322 & 0.041 & $<0.001$ \\
\hline \multicolumn{5}{|l|}{ Surgery type $($ reference $=\mathrm{ENT})$} \\
\hline anorectal, appendix & $1.29(0.96-1.74)$ & 0.253 & 0.152 & 0.097 \\
\hline bariatric, stomach, esophagus & $3.34(2.51-4.46)$ & 1.207 & 0.147 & $<0.001$ \\
\hline brain & $6.83(5.1-9.14)$ & 1.921 & 0.149 & $<0.001$ \\
\hline cardiac & $3.11(2.22-4.34)$ & 1.133 & 0.171 & $<0.001$ \\
\hline $\begin{array}{l}\text { endocrine, thyroid, parathyroid, } \\
\text { adrenal, breast }\end{array}$ & $0.92(0.69-1.25)$ & -0.080 & 0.152 & 0.602 \\
\hline gallbladder, biliary tract & $1.14(0.85-1.54)$ & 0.132 & 0.153 & 0.388 \\
\hline $\begin{array}{c}\text { hernia, peritoneum, omentum, } \\
\text { diverticulum }\end{array}$ & $1.74(1.31-2.32)$ & 0.556 & 0.146 & $<0.001$ \\
\hline intestine (not rectum) & $3.8(2.86-5.03)$ & 1.334 & 0.144 & $<0.001$ \\
\hline liver, pancreas, spleen & $6.31(4.73-8.41)$ & 1.842 & 0.147 & $<0.001$ \\
\hline obstetrics, gynecology & $2.09(1.57-2.8)$ & 0.738 & 0.148 & $<0.001$ \\
\hline orthopedic, lower extremity, pelvis & $3.3(2.49-4.37)$ & 1.192 & 0.144 & $<0.001$ \\
\hline $\begin{array}{l}\text { orthopedic upper extremity, } \\
\text { shoulder }\end{array}$ & $1.51(1.1-2.09)$ & 0.414 & 0.164 & 0.012 \\
\hline $\begin{array}{l}\text { skin, subcutaneous, other } \\
\text { musculoskeletal }\end{array}$ & $2.07(1.55-2.76)$ & 0.726 & 0.147 & $<0.001$ \\
\hline spine & $3.54(2.66-4.71)$ & 1.264 & 0.146 & $<0.001$ \\
\hline
\end{tabular}


medRxiv preprint doi: https://doi.org/10.1101/2020.06.21.20136432; this version posted June 23, 2020. The copyright holder for this preprint (which was not certified by peer review) is the author/funder, who has granted medRxiv a license to display the preprint in perpetuity. All rights reserved. No reuse allowed without permission.

\begin{tabular}{|c|c|c|c|c|}
\hline thoracic, non-esophageal & $2.94(2.16-3.99)$ & 1.078 & 0.156 & $<0.001$ \\
\hline urology & $3.08(2.31-4.1)$ & 1.124 & 0.146 & $<0.001$ \\
\hline aorta & $4.51(3.19-6.38)$ & 1.506 & 0.177 & $<0.001$ \\
\hline Vascular & $2.28(1.71-3.04)$ & 0.823 & 0.147 & $<0.001$ \\
\hline Hospital length of stay (day) & $1.05(1.05-1.05)$ & 0.050 & 0.001 & $<0.001$ \\
\hline
\end{tabular}


medRxiv preprint doi: https://doi.org/10.1101/2020.06.21.20136432; this version posted June 23, 2020. The copyright holder for this preprint (which was not certified by peer review) is the author/funder, who has granted medRxiv a license to display the preprint in perpetuity.

All rights reserved. No reuse allowed without permission.

Figure 1. 30-day postoperative mortality and readmission rates with venous thromboembolism
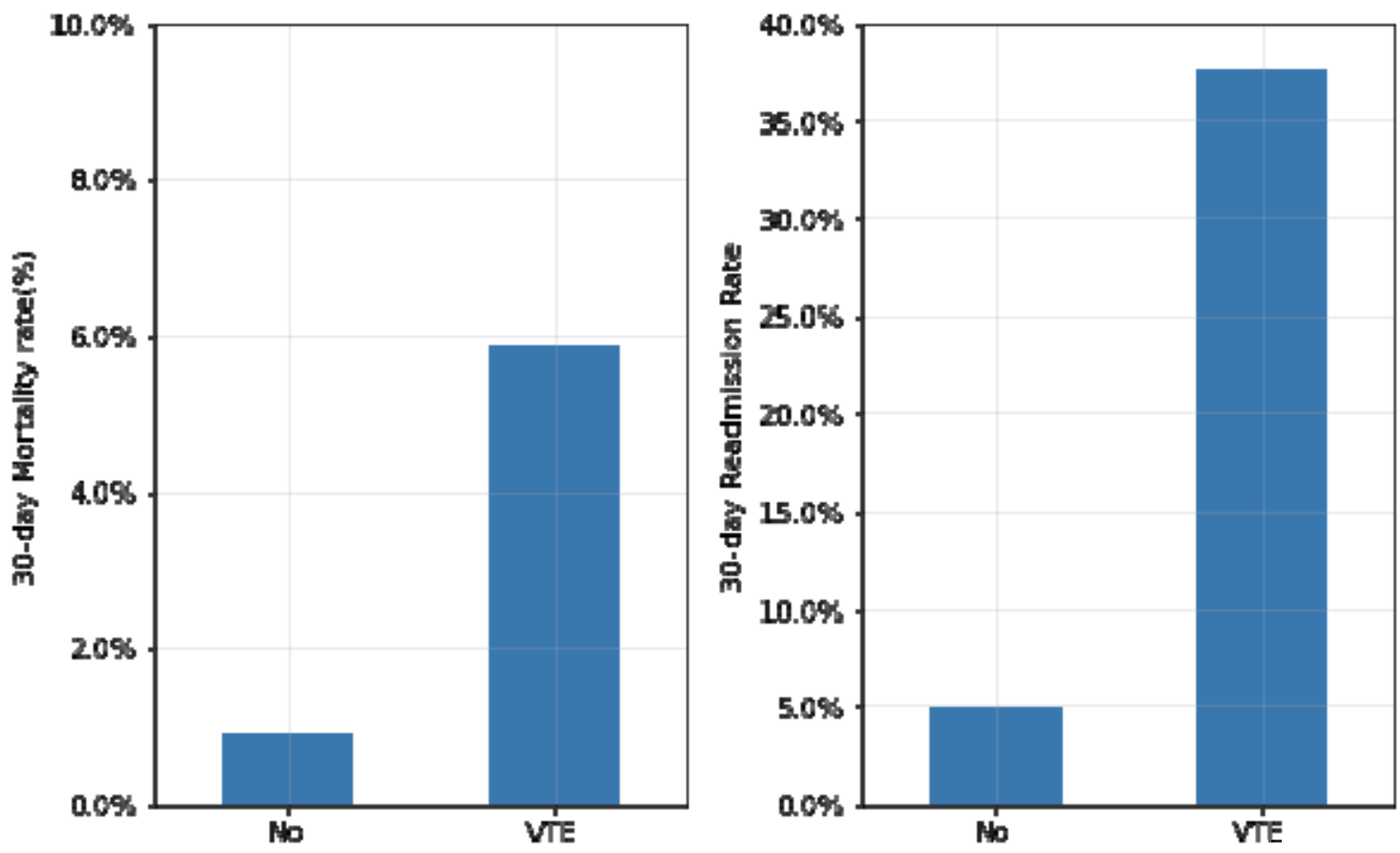
medRxiv preprint doi: https://doi.org/10.1101/2020.06.21.20136432; this version posted June 23, 2020. The copyright holder for this preprint (which was not certified by peer review) is the author/funder, who has granted medRxiv a license to display the preprint in perpetuity.

All rights reserved. No reuse allowed without permission.

Figure 2. Age, Platelet count, Serum Albumin, Length of Stay and unadjusted VTE rates. Patients from 2015 to 2017
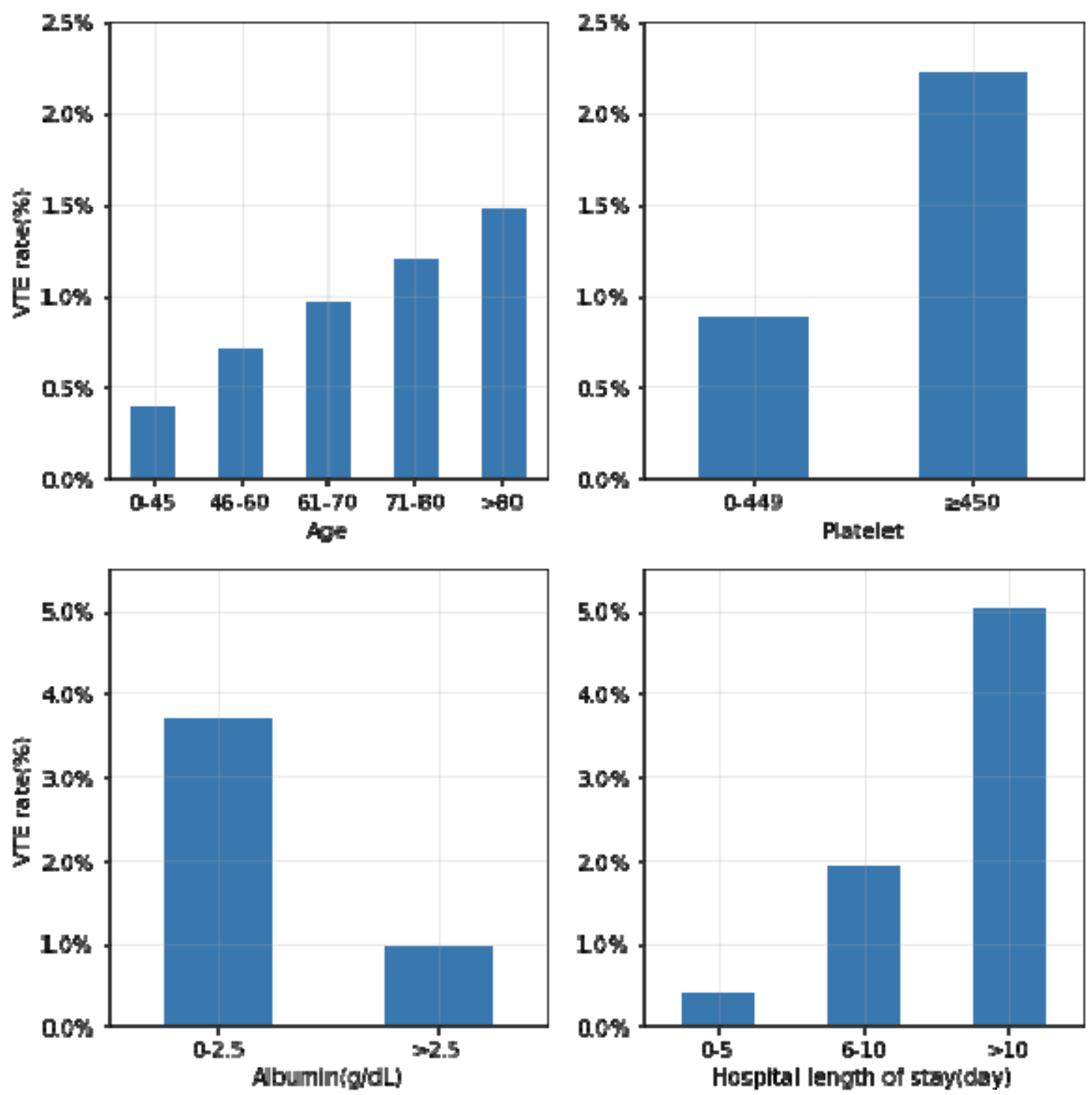
medRxiv preprint doi: https://doi.org/10.1101/2020.06.21.20136432; this version posted June 23, 2020. The copyright holder for this preprint (which was not certified by peer review) is the author/funder, who has granted medRxiv a license to display the preprint in perpetuity.

All rights reserved. No reuse allowed without permission.

Figure 3. VTE rates (\%) according to type of surgery (patients from 2015-16)

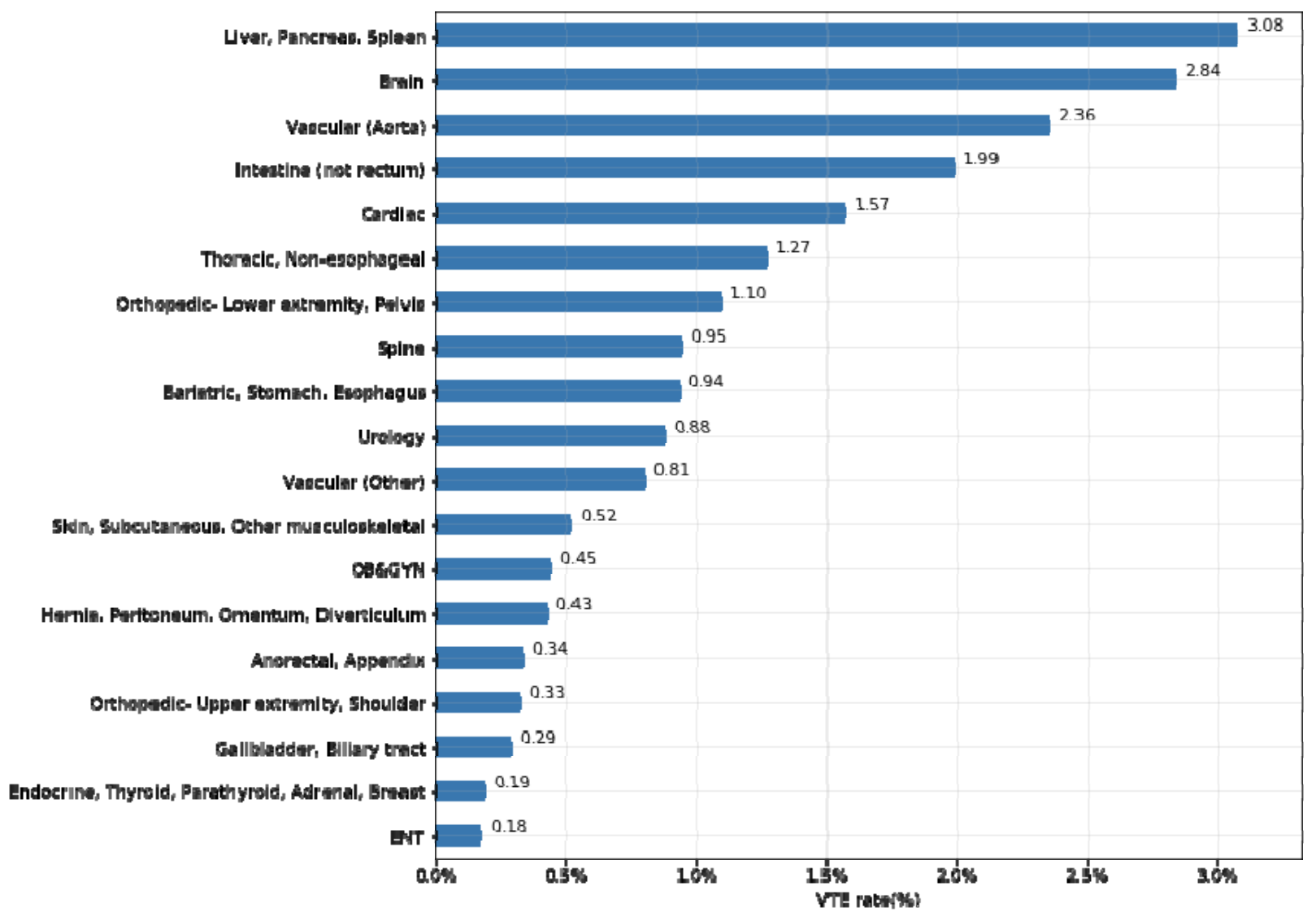

